\title{
A comprehensive study of the camel production system in the North West Coastal Zone of Egypt
}

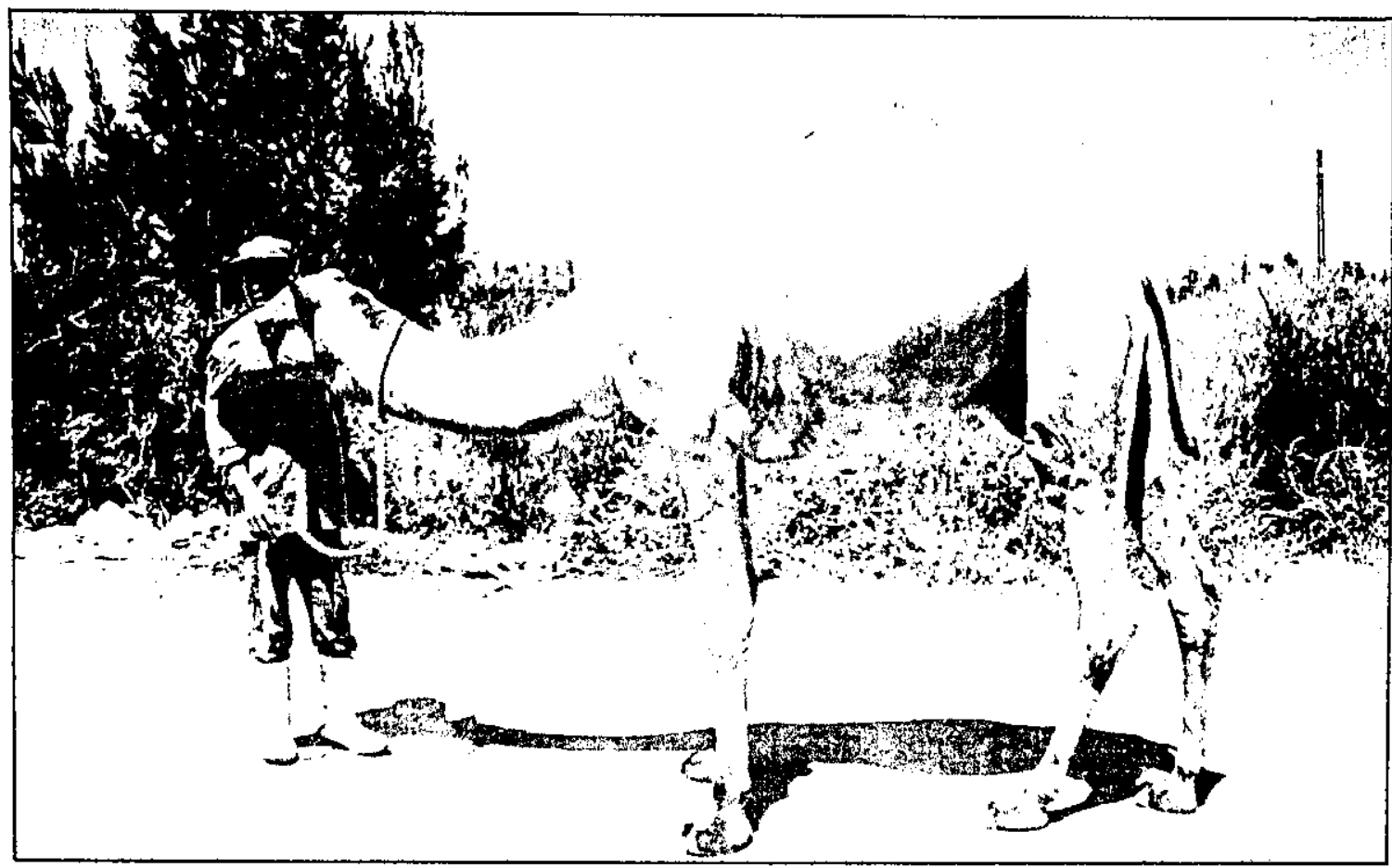

Champak Bhakat' and M.S. Sahani'

National Research Centre on Camet, Jorbeer, Bikaner - 334 001, Rajasthan, India. 


\section{Introduction}

The government of Egypt places great emphasis on .he agricultural sector for its substantial contribution to the national economy. This sector contributes about $20 \%$ of the country's GDP and comprises about $20 \%$ of tolal exports (including petroleum exports) and provides jobs for $34 \%$ of the total labour force in Egypt. The total population of the country is around 65 million, and according to the Ministry of Agriculture and Land Reclamation, the total camel population is 160,000 .

Topographically, the country can be divided into two zones i.e. the upper (southern) and lower (northern) Egypt. ihe desert region occupies more than $95 \%$ of the total area of Egypt. About $96 \%$ of Egypl's population inhabits the narrow strip of cultivated land along the Nile valley and its delta.

The Nile river covers $6500 \mathrm{~km}$ from its origin in the great African lake to the Mediterranean sea. Each year, following the torrential rains which fall on the mountain and equatorial lakes, the Nile becomes increasingly swollen until it finally bursis its bank and in a few months fills up the entire valley. By the end of May or beginning of June, the flooding reaches Egypt proper via Nubia. Untif ( ctober, the valley remains covered with beneficial layers of mud laid down by the flood, which only disappears completely at the beginning of December. As a result of this periodic flooding, the entire valley of the Nile is ticularly rich in flora and fauna. That is why Egypt is popularly known as the "Gift of the Nile".

The most common Egyptian crops are barley, maize, wheat, rice and the common leguminous crops are faba bean, lentil, soybean etc. Besides these, some other crops like groundnut, sesame and sunflower are also cultivated. The Agriculture Research Centre has also introduced some non-traditional new varieties of crops like broccoli and sweet corn. They are also cultivating different forage crops like Egyptian clover or berseem (Trifolium alexandrium). perennial clover and fodder beet millet etc. Besides these, Egyptian farmers are growing some vegetables like tomato. cucumber, garlic, etc

Different varieties of desert fruits like date, watermelon, olive, figs, papaya, jujupa, kiwi, pears and strawberry etc. are taken up. They are also culturing different
The agricultural sector contributes about $20 \%$ of the country's GDP and comprises about $20 \%$ of total exports (including petroleum exports) and provides jobs for $34 \%$ of the total labour force in Egypt. The camel (Camelus dromedarius) is an important component of the desert ecosystem, which plays an important socio-economic role within the pastoral and agriculture system in the North West Coastal Zone (NWCZ).

local varieties of fish. Besides these, the Tilapia variety and African cat fish are also cultured. Due to overpopulation in the limited strip of the Nile valley and its delta, the government has turned to desert areas to establish government organizations whose activities are geared primarily to research and development in the deserts and newly reclaimed regions of Egypt. Egyptian farmers respond positively to the findings of agriculture research, viable technology and price incentive systems.

The first author has visited different research stations and some field regions of the Arab Republic of Egypt, Ministry of Agriculture and Reclamation (MOA \& LR) in late 1999 under indo-Egypt work plan. This article discusses camel production and management systems of Egyptian farmers who inhabit the North West Coastal Zone (NWCZ) of Egypt and also rangeland management by the MOA \& LR, Egypt.

\section{Camel Production and Management in NWCZ of Egypt}

The camel (Camelus dromedarius) is an important component of the desert ecosystem, which plays an important socio-economic role within the pastoral and

1. Scientist
2. Director 
agriculture system in the NWCZ.

The majority of Egyptian camels originate from Sudan and enter into Egypt by crossing the Sudan-Egypt border. The database of the Matrouh Resource Management Project revealed that there were 12,000 heads of camel owned by $9.6 \%$ of 13,000 households in the project area. Camel ownership ranged between 2 and more than 300 head.

The average camel herd size of Egyptian farmers is 22.1 heads consisting of $74 \%$ mature females (>4years), $18 \%$ grower femaie, $2 \%$ mature males and $6 \%$ growing males. Depending upon the camel ownership, the camel herd is classified into three categories; Large (>40 head); Medium (15-40 head) and Small ( $<15$ head). The average number of stud per family ranges from zero to four. A positive and significant $(P<0.01)$ correlation was observed between camel herd size and sheep and goat flock size $(r=0.665$ and 0.539 respectively).

The camel production system in the sludy area is mainly extensive and depends on grazing on the natural rangelands. Camel herds move across a distance of 50 to $100 \mathrm{~km}$ daily seeking the range plants to futfil their requirements. Small herds are collected to constitute grazing units of about 50 to 70 heads supervised by

\section{Farmers do not pay much} attention to the health care of the camel herd. Their herds suffer from external and internal parasites like ticks, tapeworm and roundworm. About $78 \%$ of the herders do not vaccinate or treat their herds. The mortality rate varies from 16 to $20 \%$ in calves and 0 to $1 \%$ in adult camels.Some of the problems and constraints faced by the Bedouin farmers include degradation of rangelands, low productivity of herds, and inadequate veterinary services. herdsmen for $10 E$ pounds/head/month. Under the existing system, farmers keep female camels in the herd and se!l the males either just after weaning or after a fattening period depending on the financial capability or requirement of the farmers. Natural rangelands of the NWCZ consists of a variely of herbs, grasses, bushes and trees. The average grazing time of the Egyptian camel is around 9.6 hours in winter and extends to 19.4 hours during summer.

Complementary feeding is widely practiced in the area because of the shortage of pasture due to the low and erratic rainfall. Most of the farmers $(94.8 \%)$ offer concentrate to the camel throughout the year, except in good rainfall years. The period of complementary feeding is $4.5,6.1$ and 9.0 months in good, average and poor seasons respectively. The amount offered to the camel averaged $4.1 \mathrm{~kg} / \mathrm{head} /$ day, especially during late pregnancy and during lactation. About $67 \%$ of the herds come to the water points for watering in 4 to 6 day intervals during summer.

Most of the male camel calves are subjected to fattening before marketing. The fattening process starts from 4 to 12 months of age (average 4.8 months). The farmers provide concentrate to their camel in a fattening process by using a thumb rule method i.e. start with $2 \mathrm{ks} /$ head and gradualiy increase the amount until it reaches $6 \mathrm{~kg} / \mathrm{head}$. The market weight of camel calves ranges from $120 \mathrm{~kg}$ to $250 \mathrm{~kg}$ (Average $183 \mathrm{~kg}$ ).

The Egyptian camel attains puberty at the age of 5 to 7 years in case of the male and 2 to 3 years in case of the female. Age at first mating is 6.9 years for males and 4.0 years for females. The productive life of the male ranges from 18 to 30 years (average 26.4 years) and of the female ranges from 18 to 28 years (average 22.6 years). The mating season is from October to January (4.2 \pm 0.6 months) but maximum breeding $(86.2 \%)$ takes place from November to December. Average number of services per conception is $2.0 \pm 0.5$ (ranged 1 to 3 ) and calving interval is 15 to 25 months (average $22.3 \pm 3.0$ months).

The total number of calves born during the productive life of the camel is an average of $7.8 \pm 1.18$ calves and ranged between 7 to 10 calves. The number of calves weaned average $60.5 \%$. The average abortion and still birth rate in the herds is $24.0 \%$ and $4.0 \%$ respectively. The main causes of abortion are malnutrition and some diseases. Abortion commonly occurs in case of young parturati? 
females. The managemental aspects such as nutritional and health status have the greatest effect on reproductive measures. After an abortion, the first heat may come in 7 to 60 days (average 29 days) and first post-partum heat may come in 12 to 90 days (average 53 days). A mature male camel can serve 50 to 60 females during the breeding season and the suckling period ranges between 7 to 12 months. The gestation period ranges between 12 to 13 months with an average of $12.1 \pm 0.2$ months.

Milking the camel is a very difficult process under the prevailing production system, but this may not be the only reason behind the Bedouin reluctance to make use of camel milk. The other reasons are that selling camel milk is against the Bedouin's traditions and there is no market for camel milk. Very few Bedouin farmers use camel milk for their home consumption and they usually keep 2 to 3 lactating camels at home while the others are left to graze.

An Egyptian camel can produce about 1 to $6 \mathrm{~kg}$ of milk (average $3.0 \mathrm{~kg} /$ day). About $56.9 \%$ Bedouin farmers milk their animals once daily, while $43.1 \%$ milked them twice daily. The average length of lactation is 288 days (sometimes 314 days).

Egyptian farmers do not pay much attention to the health care of the camel herd. Their herds suffer from external and internal parasites like ticks. tapeworm and roundworm. About $78 \%$ of the herders do not vaccinate or eat their herds. The mortality rate varies from 16 to $20 \%$ in calves and 0 to $1 \%$ in adult camels.

The hair production of an Egyptian camel ranges from 0.5 to $3.0 \mathrm{~kg} / \mathrm{yr}$ (average $1.2 \mathrm{~kg} /$ year). There is no particular time to shear the camel hair. About $48 \%$ of the farmers shear at any time of the year, $32 \%$ of the farmers shear the animals between May to July, whereas $20 \%$ of the farmers shear them during the month of August.

\section{Camel management in some research stations under the Ministry of Agriculture \& Land Reclamation (MOA \& LR)}

Camels are reared under the intensive system in some research stations under the MOA \& LR, Egypt. The animals are fattened by using different agricultural products like straw (barley, wheat and rice) and some other by- products from the agro-industrial sector (wheat bran, rice bran, tomato bulk etc.)

Concentrate mixture is also offered to the camels this mixture contains $14 \% \mathrm{CP}, 10.5 \% \mathrm{DCP}$ and $65 \% \mathrm{TDN}$. Silage is prepared by using Egyptian clover (berseem) and perennial clover. They also provide molasses to the camels. The DM consumption of the Egyptian camel ranges from 1.8 to $2.5 \%$ of total body weight. They used to slaughter their camel at the age of 4 years and at that time, the market weight of the camel varies from $450 \mathrm{~kg}$ to $500 \mathrm{~kg}$. The dressing percentage of camel meat varies from 55 to $58 \%$ and the market price of camel meat ranges from 14 to $18 \mathrm{E}$ pounds/kg.

\section{Rangeland Management}

The Matrouh Adaptive Research Centre under the MOA \& LR, Egypt possesses a vast rangeland area of about 4000 feddan or 2000 acres. Most of the area is rainfed but some area also comes under drip, surface or canal irrigation systems. Under rangeland management development programme, plantation of different trees and shrubs like Acacia saligna, Acacia cyanophylla. Atriplex nummularia, Prosopis julifora, Atriplex canescens, Kochia indica and olive plants, are taken up.

\section{Constraints in Camel Production}

The field study monitored the opinions of Bedouins on problems and constraints facing camel production systems. These could be summarized as follows:

1. Non-availability of drinking water, especially during summer in the southern rangelands due to the low and erratic rainfall and the limited number of cisterns and reservoirs.

2. The severe degradation of rangelands especially in poor rainfall years.

3. The lack of financial credit system for supplying the supplementary feed like that which exists for sheep.

4. Restriction on access to certain areas as camel rangelands.

5. The decrease in area of rangeland as a result of expanded barley fields.

6. The general low productivity of the herds.

7. The inadequate veterinary services. $i$ 